\title{
ЦІННІСНІ ПРІОРИТЕТИ ВЧИТЕЛЯ ТА ОСВІТИ
}

\begin{abstract}
У статті розглянуто ціннісні пріоритети сучасного педагога, визначено основи педагогічної аксіології як базису ціннісної освіти. 3'ясовано, щуо нова модель української педагогічної освіти повинна грунтуватися на украӥнських національних традииіях, надбаннях вітчизняної педагогіки та критично осмисленому досвіді зарубіжжя.
\end{abstract}

Ключові слова: иіннісні орієнтації, сучасний педагог, аксіосфера, освіта, модернізація.

В статье рассмотрены иенностные приоритеты современного педагога, обозначены основы педагогической аксиологии как базиса иенностного образования. Отмечено, что новая модель украинского педагогического образования должна основываться на украинских национальных традициях, приобретениях отечественной педагогики и критически осмысленном опыте зарубежья.

Ключевые слова: иченностные ориентацчии, современный педагог, аксиосфера, образование, модернизация.

The valued priorities of modern teacher are considered in the article, bases of pedagogical axiology are marked as a base of the valued education. It is marked that the new model of Ukrainian pedagogical education must be based on Ukrainian national traditions, acquisitions of domestic pedagogic and critically intelligent experience of foreignness.

Key words: valued orientations, modern teacher, axiosphere, education, modernization.

Відродити непорушні цінності - важливе завдання суспільства, і особлива роль у його розв'язанні належить освіті. Від загальноосвітньої і вищої школи багато в чому залежить, яким буде наше суспільство завтра. Саме тому в сучасних умовах головним завданням повинно бути втілення моральності в школу виховання, де кожен має стати не тільки освіченим, а й особистістю мислячою, творчою, моральною, яка вміє жити в світі плюралізму та терпимості, за будь-якої суспільної гуманістичної системи. На II Всеукраїнському з'їзді працівників освіти наголошувалося, що національне виховання спрямовується на залучення громадян до глибинних шарів національної культури й духовності, формування в дітей та молоді національних світоглядних позицій, ідей, поглядів і переконань на основі цінностей вітчизняної та світової культури.

Meта статmі - проаналізувати підходи науковців до процесу підготовки сучасного вчителя, розвитку професійно важливих якостей педагога та окреслити ціннісні пріоритети в освіті, скорегувати понятійну базу.

О. Любар переконує: якщо педагогічні працівники утворюють страту (термін П. Сорокіна), що формує, завдяки винятковій місії вчительства, усвідомлене ставлення українців до цивілізованого стану України як у світі, так і всередині країни, то, природно, моделювання системи цінностей учительства - це насамперед діагностувальний і прогностичний моменти у визначенні найближчого майбутнього нашої країни. Україна - європейська держава, і її школа, педагоги завжди мали тісні освітні зв'язки 3 народами-сусідами, оскільки діяльність української школи $\epsilon$ складником загальноєвропейського освітнього процесу, а Україна гідно представлена в європейському освітньому колі; через те, що вітчизняна школа, освіта і педагогічна наука мають тісні зв'язки 3 освітніми системами та педагогічною культурою європейських та інших народів, українська освіта використовує їх кращі надбання та інтегрується в європейський та міжнародний освітній простір. Європа - український вибір, а освіта Європи - конгломератизована Болонською декларацією «Європейський єдиний простір вищої освіти» 1999 року. Це вже конкретний крок до реальної глобалізації освіти, про що все частіше йдеться в працях В. Андрущенка, К. Корсака, В. Кременя, М. Михальченка та інших.

Теоретико-методологічні засади аксіологічної проблематики в освіті вивчаються багатьма дослідниками (І. Бех, Б. Гершунський, М. Євтух, І. Зязюн, В. Кремінь, А. Міщенко, В. Сластьонін, Н. Ткачова, Г. Чижакова, Г. Щедровицький, А. Ярошенко та ін.), у яких педагогічна аксіологія розглядається як фундамент духовної культури майбутнього педагога. Методологія та практика аналізу сучасних педагогічних парадигм та поняття «сучасна освіта» досить повно розкриті в Національній доктрині розвитку освіти України, досліджені в працях Б. Гершунського, В. Лутая, П. Матвієнка, С. Огієнка та інших. Разом з тим поняття сучасності здатне до трансформацій під впливом, тиском політичних та соціальних чинників. Так, уже в травні 2005 р. за участю Президента України В. Ющенка у Полтаві відбувся Всеукраїнський форум «Турбота про вчителя - надія на майбутнє», на якому було прийнято програму розвитку освіти в Україні на 2005-2010 роки. На 32-й Генеральній конференції ЮНЕСКО наголошувалося, що сучасна освіта має підготувати людину до існування в складному й суперечливому соціумі. А це означає необхідність формування таких рис, як толерантність, сприйняття інших культур, релігій, цінностей, уміння спілкуватися з їхніми носіями, стати не просто громадянином світу, а й громадянином глобалізованого суспільства.

Із процесом підготовки сучасного вчителя безпосередньо пов'язаний оптимальний розвиток особистості, майбутнє людини й людства. Від рівня розвитку професійно важливих якостей педагога залежить не тільки соціально-моральне здоров'я країни, але й особисте щастя окремо взятої людини. Тому необхідно знайти педагогічно значущі резерви в підготовці сучасного вчителя. Основними векторами цього процесу є виявлення і зважена оцінка ціннісних пріоритетів сучасного педагога, 
моделювання системи освіти з урахуванням вимог третього тисячоліття як тисячоліття людини, а також розвиток аксіосфери вчителя - духовного центру соціуму. Професійний менталітет учителя визначається наявністю особливого соціально-психологічного типу особистості, до структури якого імпліцитно віднесені як типові форми психічного відображення дійсності, так і специфічні системи ціннісних орієнтацій, соціальних настанов, які індивідуально розкриваються у спрямувані на професійно-педагогічну діяльність.

Проблема професійно-педагогічних ціннісних орієнтацій переважно досліджується на рівні визначення та аналізу всього аспекту цінностей сучасного вчителя, шляхом порівняння 3 характеристиками представників інших професій, спроб класифікації згаданих вище орієнтацій педагога. Питання ціннісних пріоритетів педагога до цього часу розглядалися недостатньо, що, ймовірно, пов'язано зі складністю, міждисциплінарністю, поліфункціональністю, динамізмом самого явища ціннісної орієнтації. Необхідне практичне обгрунтування аксіологічної підготовки сучасного вчителя, аксіологізації професійно-педагогічної діяльності, розроблення інваріантного ядра ціннісноорієнтованих якостей особистості вчителя, розгляд специфіки ціннісних орієнтацій у процесі його підготовки.

Представники різних філософських шкіл (натурфілософія, неокантіанство, позитивізм, феноменологія, екзистенціалізм тощо), різнобічно оцінюючи сутність цінності, в основному розглядали це явище як стрижень стратегії життя, що формує його зміст.

Галузь педагогічної аксіології визначає ціннісні основи педагогіки й дозволяє через ціннісні пріоритети в освіті підкреслити центральну позицію людини, іiі внутрішнього світу в педагогічній системі. Природно, що стан освітньої сфери, їі розвиток і перспективи в першу чергу залежать від аксіосфери вчителя (поняття запровадив М. Каган), саме тому вважаємо доцільним досліджувати основи педагогічної аксіології в площині «педагог». У зв'язку 3 цим необхідно підкреслити актуальність педагогічної аксіології, що загострює увагу на проблемі ціннісних орієнтацій учителя, від яких залежить загальна атмосфера освітнього процесу, взаємини в системі «учитель - учень», «учитель - учитель», «учитель - батьки» тощо, якість навчально-виховної роботи, духовний потенціал молодого покоління тощо. Сутність аксіологічного підходу до підготовки спеціаліста полягає в орієнтації професійної освіти на формування в студентів системи загальнолюдських $\mathrm{i}$ професійних цінностей, що визначають їхнє ставлення до світу, своєї діяльності, самого себе як людини і професіонала.

В. Журавський поміж пріоритетних напрямків реалізації освітньої політики України визначає основні цінності та цілі, на які зорієнтовані ці дії. Професія педагога постійно вимагає не лише вдосконалення, але й підвищення якості його підготовки, спрямованої на посилення емоційної складової професії, розвиток емпатії як вияву любові, доброти, милосердя до іншої людини. Тому стає зрозумілою увага вчених до питань розвитку духовного спілкування педагога, орієнтованого на цінність іншої людини, передачу моральних цінностей, становлення комунікативної культури. Необхідно звернути увагу на актуальність проблеми, пов'язаної з розвитком професійного стилю сучасного вчителя, яка грунтується на позитивних стереотипах і сублімує творчий потенціал педагогічної праці. Ціннісні орієнтації вчителя можуть виступати як постулати, необхідні для повноцінної діяльності, а розвиток умінь користуватися ними дозволить творчо розв’язати проблеми педагогічної діяльності.

Особливе значення має виявлення ціннісних переваг особистості у професійній сфері. Відповідь на питання про те, на які цінності орієнтується вчитель, дозволяє з'ясувати реальний стан сучасного педагога, силу його впливу на соціокультурні процеси в суспільстві, потенційні можливості вчительства як соціальної страти для майбутнього розвитку України.

Зважаючи на те, що в ціннісних орієнтаціях може акумулюватися весь життєвий досвід особистості, який детермінує взаємозв'язки 3 навколишнім світом і діяльність людини, важливо звернутися i до проблеми формування аксіосфери вчителя 3 посиленням людиноцентричних тенденцій. Нарешті, вивчення професійно-педагогічних орієнтацій сучасного й майбутнього педагога надасть можливість прогнозувати ситуацію в освітній сфері, що має принципове значення для розвитку теорії і практики педагогічної науки.

Президент США Дж. Буш на презентації національної освітньої програми виголосив тезу про те, що сучасний рівень освіти визначається не тільки тим, які студенти досягають успіхів, але й тим, які нації розвиваються у тісному світі вільного підприємництва. Він закликав думати про зміни, які трансформують світ. На його думку, упродовж історії людства ресурсами вважалися грунти та каміння, землі й багатства, накопичені в минулому. Але найбільшим багатством $\epsilon$ інтелект, геніальність, здатність людського розуму.

На думку О. Бодальова, це завдання буде дійсно розв’язаним, якщо такі загальнолюдські цінності, як збереження планети Земля, благо Батьківщини, інша людина, робота, родина, створені людьми багатства культури, стануть власними цінностями людини, й у неї будуть сформовані високі потреби і здібності не тільки оберігати ці цінності, але й обов’язково примножувати.

Отже, аксіологічний підхід до професійно-педагогічної підготовки передбачає формування в студентів системи ціннісних орієнтацій, які визначають загальне спрямування інтересів і прагнень 
особистості, ієрархію індивідуальних переваг, мотиваційну програму діяльності і, в результаті, рівень готовності майбутнього спеціаліста до реалізації життєвих і професійних планів, становлення інтелігента, інтелектуальної еліти демократичної незалежної України.

\section{Література}

1. Виховання молодого покоління на принципах християнської моралі в процесі духовного відродження України / Матеріали III Міжнародної наук.-практ. конференції. - Острог, 1998. - 444 с. 2. Вишневський О. Сучасне українське виховання / О. Вишневський // Педагогічні нариси. - Львів, 1996. 3. Воловик В. И. Философия педагогики / В. И. Воловик. - Запорожье: Просвіта, 2003. - 152 с. 4. Гроф С. Психология будущего: Уроки современных исследований сознания / С. Гроф. - М. : АСТ, 2003. - 458 с. 5. Журавський В. С. Вища освіта як фактор державотворення і культури в Україні / В. С. Журавський. - К.: ВД «Ін Юре», 2003. - 416 с. 6. Любар О. Опанування майбутніми вчителями української педагогічної культури / О. Любар // Вища школа. 2002. - № 4-5. - С. 49. 7. Огневьюк В. Образование как сфера «будущего времени» / В. Огневьюк // Персонал. - 2003. - № 9. - С. 66. 8. Суїменко Є. Феномен незнання, або Дещо про освічене неуцтво. / Є. Суїменко // Соціологія: теорія, методи, маркетинг. - 1999. - №3. - С. 216. 9. Тоффлер А. Футурошок /А. Тоффлер. - СПб. : Лань, 1997. - 464 с. 10. Україна: Проблеми самоорганізації: [у 2 т.] / В. Кремень, Д. Табачник, В. Ткаченко. К. : Промінь, 2003. - Т. 2: Десятиріччя суспільної трансформації. - 464 с. 